\title{
Postura gerencial estratégica buffer: um estudo realizado em pequenas e médias empresas
}

\author{
Buffer management strategic posture: a study in small and medium enterprises
}

Anderson Queiroz Lemos ${ }^{[a]}$, Francisco Roberto Pinto ${ }^{[b]}$, Elias Pereira Lopes Júnior ${ }^{[c]}$

[a] Mestre em Administração pela Universidade Estadual do Ceará (UECE), professor do curso de Administração da Universidade Estadual do Ceará (UECE), Fortaleza, CE - Brasil, e-mail: andersonqadm@gmail.com

[b] Doutor em Administração pela Universidade Federal da Paraíba, professor do Programa de Pós-Graduação em Administração em Administração da Universidade Estadual do Ceará (UECE), Fortaleza, CE - Brasil, e-mail: rpinto@secrel.com.br

[c] Mestre em Administração pela Universidade Estadual do Ceará, professor do curso de Administração da Faculdade Sete de Setembro, Fortaleza, CE - Brasil, e-mail: eliasjunior08@gmail.com

\section{Resumo}

Este artigo aborda a teoria dos stakeholders para o gerenciamento estratégico, dando continuidade aos estudos de Meznar e Nigh (1995) ao analisar alguns fatores ambientais explicados principalmente pela Teoria da Contingência e Teoria da Dependência de Recursos. A literatura utilizada foi selecionada com base na contribuição dos autores para o desenvolvimento das teorias organizacionais e do gerenciamento estratégico, assim a pesquisa pode ser caracterizada como exploratória no sentido do resgate da literatura. 0 objetivo deste estudo foi predizer a intensidade com que as empresas adotam uma postura gerencial de proteção e bloqueio (conhecida como buffer) frente às influências de variáveis externas e internas às suas estruturas. Foram coletados dados junto a 74 gestores de Pequenas e Médias Empresas (PMEs) da Região Metropolitana de Fortaleza, Ceará. Na fase de análise dos dados empíricos, procedeu-se inicialmente à avaliação exploratória preliminar. Os dados foram avaliados por meio de análise descritiva e da técnica de análise de regressão. Verificou-se especialmente que: (1) em geral, apesar do pequeno porte, as empresas possuem um nível intermediário de adoção desta postura; (2) esta postura é fortemente influenciada pelos seguintes determinantes: incertezas ambientais, compostas pelas turbulências e complexidade existentes no ambiente; o porte da empresa e o seu nível de visibilidade pública. Apesar das limitações deste estudo, acredita-se que ele possa servir para enriquecer o tema do gerenciamento estratégico de stakeholders, principalmente no que concerne ao aprofundamento empírico sobre o tema das posturas gerenciais estratégicas.

Palavras-chave: Gerenciamento estratégico. Postura gerencial. Meio envolvente.

\section{Abstract}

This article has the overall theme of the stakeholder approach to strategic management. Its discusses some environmental determinants explained by the Theory of Contingency and Resource Dependence Theory. From these 
theories emerge some constructs (determinants) internal and external in organizations, that predict whether firms will adopt a posture of protection and management block known as buffer. The field study was conducted with data collected from the 74 managers of Small and Medium Enterprises (SMEs) in the metropolitan area of Fortaleza-Ceará. The data were evaluated by descriptive analysis and technical analysis of regression. It was especially checked that: (1) in general, companies have an intermediate level of adoption of this posture; (2) this approach is strongly influenced by the following determinants: environmental uncertainties, which composed of the turbulence and complexity in the environment, by the size and level of public visibility. Despite the limitations of this study, it is believed that it can serve to increase the volume of empirical studies that address the strategic management of stakeholders, particularly concerning the deepening of the empirical strategic management postures.

Keywords: Strategic management. Public affair. Environment.

\section{Introdução}

Desde meados do século $\mathrm{XX}$, percebe-se que as mudanças ambientais estão mais frequentes, de forma que as características mais observáveis são a velocidade e a intensidade, que se caracterizam como sociais, econômicas, políticas, ambientais, dentre outras. As inconstâncias ambientais escondem oportunidades e ameaças que geram interesse e preocupação aos investidores, conhecidos como Shareholders, pois a sobrevivência das empresas depende da forma com que elas irão interagir com o meio envolvente.

As mudanças no comportamento da sociedade na década de 1980 fizeram surgir uma área funcional com preocupações estratégicas nas empresas privadas norte-americanas. Esta nova área tem por função gerenciar estrategicamente os objetivos das empresas, mantendo atenção no que se passa externamente as suas fronteiras. Na prática, o gerenciamento estratégico visar criar uma interface entre os objetivos da empresa e os dos atores externos. Esta área que promove a interface é chamada de public affair (POST et al., 1983). Segundo Meznar e Nigh (1995), o aspecto fundamental desta atividade é a manutenção da relação da organização com os atores externos.

Para Meznar e Nigh (1995), cinco podem ser as variáveis determinantes que predizem a adoção da postura estratégica buffer, que pertencem tanto ao ambiente externo quanto ao interno das organizações, independente de seu porte. Os aspectos externos são conhecidos como 'meio envolvente contextual'. As variáveis supostamente determinantes observadas por Meznar e Nigh (1995) foram: tamanho da empresa; Nível de visibilidade pública; Iniciativa estratégica; Importância dos recursos possuídos; Nível de incerteza ambiental externa.
As posturas gerenciais empresariais vêm sendo estudadas por vários pesquisadores (MEZNAR; NIGH, 1995; HARRISON; ST. JOHN, 1996; SCOTT, 1998; FREEMAN; McVEA, 2001; CARDOSO; SCHENINI; RENSI, 2004; ANTUNES, 2006), entretanto com finalidades e contextos diferentes. 0 que há de comum entre estes estudos é a disposição para criar trabalhos que legitimem as posturas gerenciais dentro de uma perspectiva pragmática.

No Brasil existe um grande volume de trabalhos acadêmicos que versam sobre estratégia e também sobre stakeholders, muitos deles influenciados pelo espaço nos anais de congressos destinados a estes temas. Entretanto, ainda carece de trabalhos, principalmente os empíricos, que abordam o tema das posturas gerenciais estratégicas no contexto organizacional brasileiro.

0 presente trabalho vem acompanhando a recente série de estudos sobre os preditores ambientais (endógenos e exógenos) das posturas gerenciais estratégicas. Ademais, insere-se no tema de pesquisa de importantes programas de pós-graduação em Administração no Brasil. Neste artigo, o foco concentra-se na postura empresarial de proteção, conhecida na literatura do gerenciamento estratégico como public affair buffer, ou simplesmente postura gerencial bloqueio (MEZNAR; NIGH, 1995).

0 trabalho se embasa na pesquisa de Meznar e Nigh (1995), na qual eles estudaram como as grandes corporações norte-americanas se protegiam das incertezas ambientais por meio da adoção de certas estratégias. Como o universo empresarial pesquisado possui outra realidade, o objeto desta pesquisa foi as Pequenas e Médias (PMEs) organizações que operam na indústria, no comércio e no serviço da Região Metropolitana de Fortaleza. 
Da mesma ordem de grandeza das dimensões continentais do Brasil, estão os desafios de sobrevivência das micro, pequenas empresas (MPEs). Estas categorias de empresas somam 98\% das empresas formais no país. As MPEs ocupam $67 \%$ da mão de obra do setor privado nacional e $20 \%$ do Produto Interno Bruto (PIB) (BEDÊ et al., 2006).

Em relação ao ponto de vista microeconômico, Teixeira, Andrade Júnior e Banganga (1998) afirmam que as vantagens da MPEs são muitas com relação às grandes empresas. Este porte de empresas é identificado como flexível e menos burocratizada, o que lhe permite respostas mais rápidas e mais adequadas ao ambiente.

No Brasil existem micro, pequenas e médias empresas que operam no ambiente da indústria, do comércio e na prestação de serviços. Hoje, dentro do universo de 184 municípios no estado do Ceará, existem aproximadamente 99.274 estabelecimentos no comércio, 24.980 no setor de serviços e 20.775 na indústria (BEDÊ et al., 2006).

Conforme Bedê et al. (2006), os produtos oferecidos no varejo, em MPEs, possuem baixo valor unitário e estão associados a atender às necessidades básicas da população (alimentos, vestuário, material de construção). Outra característica deste grupo de empresas é que a média de funcionários com registro em carteira é baixo.

Hoje, se sabe que existe uma relação de dependência entre o tipo de postura adotada por uma organização e a influência das condições exógenas. Para investigar esta relação funcional no cenário das PMEs nacionais, formula-se a seguinte pergunta de partida: Qual a intensidade, com que tamanho da empresa, o nível de visibilidade pública por ela possuída, a iniciativa estratégica, a importância dos recursos possuídos e as incertezas do macroambiente estimulam os dirigentes a adotarem a postura de proteção buffer?

Os objetivos definidos para a pesquisa foram: (1) avaliar o nível de adoção da postura gerencial buffer pelas PMEs da Região Metropolitana de Fortaleza; (2) analisar os principais fatores ambientais internos e externos de influência sobre adoção desta postura.

Deste modo, tem-se aqui a oportunidade de desenvolver um estudo válido enquanto referencial específico para corroborar no desenvolvimento de dimensões preditoras de um comportamento estratégico empresarial.

Para atingir o objetivo, o trabalho está dividido da seguinte forma. Inicialmente apresenta-se a fundamentação teórica, tipificando a postura gerencial estratégica de relacionamento buffer. Em seguida, apresenta-se as dimensões preditoras anteriormente utilizadas por Meznar e Nigh (1995). 0 trabalho continua com as hipóteses propostas. Por fim, os aspectos metodológicos e a análise dos resultados.

\section{Revisão teórico-empírica}

A pesquisa está embasada na Teoria da Contingência, na Teoria da Dependência de recursos, na estratégia empresarial. Estas teorias são necessárias para embasar as hipóteses apresentadas ao final do referencial teórico.

\section{Debate sobre a postura gerencial estratégica buffer}

Como as organizações privadas vêm gerenciando suas relações com o governo e com a sociedade? Adaptando-se às pressões do ambiente ou utilizando-se de recursos possuídos para modificá-lo? Propor iniciativas sociais e políticas que assegurem a legitimidade organizacional pode ser considerado estratégico? Estas perguntas são fundamentais para iniciar uma discussão sobre a forma com que as empresas têm gerenciado suas relações com seus stakeholders externos.

0 arrojo em que se apoia o tema sobre o gerenciamento dos interesses dos stakeholders está em procurar meios que possam minimizar as preocupações de gestores que sofrem as incertezas ambientais e assim ajudá-los a entender o ambiente em que suas firmas operam. Estudar sobre o gerenciamento estratégico de stakeholders é fundamental para inferir sobre as posturas que as organizações adotam para administrar seus interesses.

Quando Freeman (1984) surgiu com o tema sobre a abordagem dos stakeholders na estratégia empresarial, ele expôs à academia o ímpeto por traz do gerenciamento de interesses dos stakeholders. Para este autor, as organizações não podem ser vistas desassociadas dos temas éticos, principalmente no processo de elaboração de suas estratégias empresariais. Freeman (1984, p. 46) define stakeholder como qualquer parte que "pode afetar ou é afetado pelos resultados alcançados nos objetivos de uma organização".

A origem das pesquisas sobre posturas gerenciais no contexto do gerenciamento estaria no que Meznar e Nigh (1995) chamam de public affairs activities ou 
atividades de relações públicas. Para estes autores, as relações que as organizações possuem com o ambiente podem ser traduzidas em formas de posturas.

Meznar e Nigh (1995) estudaram quais variáveis determinariam uma empresa adotar a postura gerencial de bloqueio e proteção. As variáveis estavam presentes no interior e no exterior das organizações. 0 contexto pesquisado foi o que envolvia grandes empresas norte-americanas. As variáveis que mais exerceram influência nas atitudes dos gestores com relação à postura de proteção foram o tamanho e a importância dos recursos possuídos pelas empresas. Antunes (2006), em sua pesquisa de mestrado, relaciona postura gerencial a alguns fatores como: estilo gerencial, o tipo de relacionamento que os dirigentes possuem com seus stakeholders, a estrutura organizacional (tecnologia central), as aquisições, e o relacionamento com os colaboradores.

As características da postura e o papel da alta gerência no ambiente do varejo são: Catalisadora, patrocinadora, viabilizadora, incentivadora e receptiva. Antunes (2006, p. 168) entende que estas características são assim pelo fato de que "o varejo busca uma adequação reativa, de curto prazo ao ambiente externo".

A literatura que versa sobre o gerenciamento estratégico apresenta um tipo de postura gerencial básica que pode ser utilizada por organizações quando estas se relacionam com agentes externos, esta postura é conhecida como buffer (MEZNAR; NIGH, 1995; SCOTT, 1998; FREEMAN; McVEA; 2001).

O trabalho de Harrison e St. John (1996) associa a postura gerencial buffer a diversas estratégias. Estas podem ser utilizadas para incentivar a competição entre os fornecedores, enfatizar individualismo e a competição no mercado, juntar esforços para realizar lobby junto ao governo, contribuir financeiramente com partidos políticos para conseguir vantagens.

Para Antunes (2006), quando uma organização adota estratégias do tipo buffer (proteção), estas visam proteger as competências essenciais da firma (por exemplo, tecnologia) das incertezas ambientais, para assim operarem com mais efetividade organizacional.

A postura gerencial do tipo buffer é interpretada como uma abordagem tradicional que restringe os efeitos dos stakeholders externos na firma. Inclui atividades de inteligência e estudo do ambiente como: pesquisa de marketing, relações públicas e planejamento. É característico desta postura empresarial erguer barreiras entre a firma e o stakeholder externo e a baixa flexibilidade nas mudanças internas (HARRISON; ST. JOHN, 1996).

Para Antunes (2006), existe uma contradição entre alguns autores (SCOTT, 1998; LOWENDAHL; REVANG, 1998) sobre em qual ambiente as organizações tendem a operar com as estratégias do tipo buffer. Para Lowendahl e Revang, (1998), estas estratégias devem ser utilizadas à medida que o ambiente externo se torne mais complexo.

Para Scott (1998), as estratégias do tipo buffer têm de ser utilizadas em ambientes de baixa complexidade externa, assim, suportariam o uso de rotinas padronizadas e produção em massa. Segundo Antunes (2006, p. 25), a razão para suportar este argumento é:

À medida que a complexidade externa aumenta, os custos associados com a busca pela estabilidade (utilização de estratégias de buffering) aumentam e, mais ainda, a estabilidade provocada pela utilização desta estratégia irá diminuir a flexibilidade e os benefícios dela decorrentes.

Conforme Meznar e Nigh (1995), quando uma organização desprende energia para manter as intempéries ambientais longe de influenciar as suas operações internas, a mesma está adotando a postura buffer. Para estes autores, a contrapartida desta postura às interferências externas é procurar influenciar o ambiente na qual ela opera, de forma que práticas antiéticas (uso de lobistas, influenciar os agentes do governo por meio de suborno e dossiês, contratação de firmas de assessoria jurídica), podem chegar a ser utilizadas para que os objetivos traçados sejam alcançados.

\section{Definições do estudo: teorias e hipóteses}

A partir da revisão de alguns estudos empíricos e teóricos com objetivos semelhantes ao deste artigo, da exaustiva discussão entre os autores e de consultas a outros pesquisadores interessados no tema, ficou definido que as variáveis dependentes seriam as mesmas utilizadas por Meznar e Nigh (1995) e definidas em cinco dimensões: Nível de incerteza do macroambiente; Tamanho da empresa; Importância dos recursos possuídos; Nível de visibilidade pública; Iniciativa estratégica. As dimensões estão descritas a seguir. 


\section{As incertezas ambientais}

As incertezas ambientais são vistas por Leal (2005) como dificuldades para as organizações serem mais eficientes e eficazes. Elas afetam diretamente a previsibilidade, de forma que a relação previsibilidade, eficácia e eficiência organizacional, e incerteza ambiental constituem juntas importantes aspectos nas quais estudos são baseados.

Para Meznar e Nigh (1995, p. 3), "altos níveis de incertezas ambientais têm sido constantemente interpretados como ameaça à eficiência e eficácia organizacional". Observar o ambiente externo é então fundamental, pois existem certos determinantes e que incentivam a adoção da postura gerencial estratégica.

Quando pesquisamos sobre ambiente organizacional estamos inferindo sobre a totalidade de fenômenos que afetam as organizações, tanto internamente quanto externamente. No fim do século XX, os estudos sobre gestão organizacional e sua associação com as variáveis macroambientais tornaram-se uma das mais importantes questões sobre o tema do comportamento organizacional. Para Henriques e Sadorsky (1999), estas questões afetam todos os níveis de operação da empresa.

É a teoria da contingência que vem explicar a mudança de visão do que acontece no ambiente interno organizacional para o externo. As consequências desta mudança de referencial são o que Brown e Eisenhardt (2004) consideram como o maior desafio estratégico das organizações do século XXI, ou seja, administrar a mudança.

Entre 1995 e 2008, diversos foram os trabalhos que se basearam na teoria da contingência. São exemplos de estudos que utilizam a teoria da contingência em diversos temas da gestão empresarial: postura gerencial estratégica (MEZNAR; NIGH, 1995), sistema de contabilidade gerencial (MOLINARI; GUERREIRO, 2004), estrutura de gestão em cursos superiores de contabilidade em instituições particulares (FAGUNDES et al., 2008).

Algumas variáveis referentes à turbulência e à complexidade que podem incorrer no contexto político e social, e que geralmente acometem as empresas são: A rápida evolução das regulamentações; Demandas sociais de grupos organizados que mudam frequentemente; Elevado nível de regulamentação das agências do governo; Excesso de agências regulamentadoras (MEZNAR; NIGH, 1995).
Conforme seja o grau de incerteza do setor no qual a firma se insere, torna-se difícil de prever o que pode acontecer. Desta forma, para alguns gestores, adaptar-se ao ambiente pode ser uma estratégia cara e difícil de ser realizada sem que alterações na estrutura interna das organizações ocorram (MEZNAR; NIGH, 1995).

\section{A dependência dos recursos e as posturas gerenciais}

Independente da natureza da organização, seja esta política, econômica ou social, esta somente continuará operando no sistema se seus produtos/serviços ou suas ações estiverem em conformidade com os padrões de valor da sociedade (MEZNAR; NIGH, 1995).

A Teoria da Dependência dos Recursos enfoca no macroambiente organizacional e defende que toda e qualquer organização, inclusive as sem fins lucrativos (ONGs), dependem de alguma forma do ambiente externo. Para Prado e Takaoka (2001, p. 7), "essa dependência externa é baseada no controle externo de alguns recursos que a organização necessita".

0 modelo proposto pela Teoria da Dependência de Recursos leva em conta as decisões e ações organizacionais. Os três grandes autores que contribuíram para o desenvolvimento desta teoria foram Aldrich, Pfeffer e Salancik. As parcerias científicas realizadas por eles na década de 1970 resultaram em grandes contribuições para a teoria da dependência de recursos.

A premissa básica do modelo desta teoria é que as decisões são tomadas no interior das organizações pela alta hierarquia e são baseadas no contexto político interno destas organizações (HALL, 2004).

Segundo entendem Meznar e Nigh (1995), nem todas as organizações terão o mesmo grau de vulnerabilidade no ambiente, o tamanho de uma organização e a importância dos recursos que ela oferece são fatores determinantes do seu poder. Para estes autores a relação entre tamanho e importância de recursos é direta, ou seja, quanto maior for a organização e mais importante forem seus recursos, consequentemente mais poder a firma deterá.

0 poder é um dos temas centrais nas ciências sociais. Para a administração, seus estudos estão concentrados nas relações entre a organização e os stakeholders internos e externos. A variável poder é relacional, ou seja, não possui significado a não ser que seja praticado. Segundo entende Hall (2004), o poder pode ser claramente observado quando introduzimos a ideia de dependência entre partes. Por exemplo: um indivíduo 
A obriga um indivíduo B a realizar alguma atividade, mesmo que o indivíduo B não queira.

Freeman e McVea (2001) entendem que o poder que a organização possui pode influenciar para que ela não se adapte ao ambiente, de forma que estratégias do tipo buffer, como espionagem industrial, lobby, suborno, contratação de advogados especializados em temas socioambientais, chegam a ser utilizadas para assegurar que os objetivos delineados pelas firmas sejam obtidos ou que suas competências essenciais estejam seguras de imitação.

Pfeffer e Salancik (1978) entendem que existem fatores chave que determinam o poder de uma organização, seriam estes: o tamanho e a importância dos recursos controlados pela organização. Para estes autores, a visibilidade pública que uma organização possui também seria um indicador de controle ambiental, entretanto não seria considerada parte do poder organizacional.

\section{Tamanho}

Existem diversos critérios para definir o porte de entidades organizacionais. No Brasil, o tamanho de uma organização pode ser definido pelo número de empregados que estão diretamente vinculados a ela, ou ainda pelo faturamento anual. Motta (1991) é um autor de teoria organizacional que associa o tamanho de uma organização com o número de funcionários e os ativos críticos por ela possuídos.

O tamanho da organização está diretamente associado ao poder que ela tem para influenciar o ambiente externo. Neste sentido, algumas empresas estão mais suscetíveis a sucumbirem às pressões ambientais que outras empresas. 0 pressuposto é que o tamanho da organização seja variável fundamental para a condição de adaptação às exigências do ambiente.

Ferrell, Fraedrich e Ferrel (2001) entendem que existe uma relação entre o tamanho e os ativos possuídos pela organização e a sua capacidade de modificar o ambiente em seu favor. Esta relação é um tanto óbvia, entretanto as pesquisas sobre RSC em PMEs ainda não esgotaram todas as possibilidades explicativas dos pressupostos desta relação.

Uma das maneiras pela qual os tomadores de decisões estratégicas escolhem a postura a ser adotada baseia-se nas condições internas da organização. Isso sugere limitações econômicas, ou seja, "alguns projetos podem ser muito onerosos. Mercados podem ser tão dominados por poucas empresas, a ponto de tornar impossível uma empresa nova e pequena entrar" (HALL, 2004, p. 253).

Além da barreira de entrar num determinado mercado, outras decisões para tentar influenciar o ambiente podem não ser possíveis para as pequenas organizações. Segundo Hall (2004, p. 253), "organizações de pequeno porte, por exemplo, têm muito menos poder do que grandes organizações para alterar seus ambientes".

O estudo realizado por Meznar e Nigh (1995) em 89 empresas norte-americanas levantou uma hipótese que relacionava o tamanho da organização à intenção desta em modificar as condições ambientais. A hipótese foi que o tamanho de uma organização tem associação positiva com a postura de proteção buffer.

O que Meznar e Nigh (1995) afirmam sobre a relação entre organizações, sociedade e governo é que caso estes grupos de interesse tentem revogar a legitimidade de certas organizações, estes grupos de stakeholders podem incorrer em consequências não previstas. "Para organizações poderosas, utilizar estratégias do tipo buffering torna-se factível" (MEZNAR; NIGH, 1995, p. 4).

0 resultado encontrado pelos autores após o tratamento de dados foi positivo para a hipótese testada. A relação entre tamanho e postura gerencial buffer foi comprovada pelo coeficiente Beta $(\beta=0,44)$ e estatisticamente significante para $\mathrm{p}<0,01$. Conforme os autores, o tamanho da organização foi a variável mais importante (dentre todas por eles utilizadas) para explicar o comportamento de proteção buffer das organizações pesquisadas.

\section{Importância dos recursos}

Para Pfeffer e Salancik (1978), um dos fatores mais importantes que uma organização pode possuir para estabelecer sua posição de dominação sobre o ambiente, está relacionado à importância dos recursos que ela controla. Controle denota poder, então, se uma organização possui um determinado nível de poder sobre o ambiente externo, naturalmente possui subsídios para controlar este meio (MEZNAR; NIGH, 1995).

Prado e Takaoka (2001), quando propuseram um modelo para análise de terceirização em empresas de Tecnologia da Informação (TI), entenderam, para o propósito de seu artigo, que a terceirização era determinada pelos recursos críticos possuídos pela firma 
candidata. Isto implica dizer que tomar uma decisão está baseada numa função, no caso da pesquisa dos autores foi na relação Terceirização $=\mathrm{f}$ (recursos críticos).

Apesar de existirem empresas e setores mais propensos a deterem poder sobre os atores que atuam no ambiente externo, existem outras empresas de outros setores que não gozam de recursos que sejam importantes o suficiente para serem vitais à sobrevivência da sociedade. Algumas destas empresas oferecem produtos/serviços supérfluos.

Para Meznar e Nigh (1995), estas empresas seriam menos propensas a resistirem às pressões de grupos organizados e de agências reguladoras do governo, estando assim suscetíveis a compartilhar recursos, adotarem posturas mais moderadas e até mesmo acomodadas. Pelo fato da sua legitimidade não estar associada à importância do produto/serviço por ela oferecido, é provável que estas empresas adotem uma postura de adaptação às exigências dos grupos externos.

Ao associarem a importância dos recursos possuídos com o tipo de postura gerencial buffer adotada pelas empresas, a hipótese inicial de Meznar e Nigh (1995) era que a correlação seria positiva, ou seja, importância de recursos influencia na adoção desta postura.

Os autores comprovaram a hipótese descobrindo evidências de correlação entre estes construtos. Apesar de baixa, a associação foi estatisticamente significante para $\mathrm{p}<01$. Esta descoberta reforça o argumento de que organizações poderosas se engajam mais nas atividades de proteção e bloqueio de suas competências distintivas.

\section{Visibilidade pública}

O tema da visibilidade tem sido identificado por diversos autores como um importante atributo estratégico para as organizações. Diversas são as nuanças em que se encontram os trabalhos sobre visibilidade. Meznar e Nigh (1995) associaram de forma positiva a visibilidade às posturas de proteção (buffer); Meznar e Nigh (1995) relacionaram positivamente tamanho à visibilidade pública; Brammer e Millington (2001) realizaram um estudo empírico com 300 empresas do Reino Unido para relacionar visibilidade e suas práticas de RSC; Fossá e Sgorla (2008) relacionaram a visibilidade midiática das organizações sobre suas práticas de RSC como estratégia de legitimação social, de forma que os objetos de pesquisa foram duas fábricas de calçados.
Meznar e Nigh (1995) levantaram hipóteses relacionando a visibilidade pública empresarial possuída à postura gerencial adotada e ao tamanho da empresa. A hipótese de que visibilidade tem associação positiva com postura buffer foi refutada $(\beta=-0,1)$. Estes autores também associaram o tamanho da empresa a sua visibilidade pública. Desta vez o resultado encontrado indicou que a hipótese foi fortemente comprovada $(\mathrm{p}<0,01)$, ou seja, há uma grande associação entre visibilidade e tamanho da empresa.

As evidências empíricas atuais percebem o tamanho como uma forma de mensurar a visibilidade da organização. Segundo Brammer e Millington (2006, p. 7), "no contexto dos estudos sociais e organizacionais, o tamanho da organização tem demonstrado ser um fator determinante de influência no ambiente em que a organização opera".

Empiricamente estes autores testaram a hipótese de que filantropia empresarial e a visibilidade organizacional, que são fatores controláveis, são positivamente associadas. A hipótese foi aceita com um nível de significância estatística muito bom $(\mathrm{p}<0,0000)$ de haver relação positiva entre as variáveis estudadas.

Conforme Fossá e Sgorla (2008), a maneira com que as organizações se mostram para os campos sociais é por meio dos veículos de comunicação (jornais, revistas, televisão, internet, dentre outros), e isto caracterizaria a visibilidade midiática. Conforme seja o grau de exposição pública destas empresas, "a sua visibilidade organizacional estaria associada à elevação do nível de regulação dos stakeholders" (BRAMMER; MILLINGTON, 2001, p. 7).

Utilizar a visibilidade da empresa para o alcance de estratégias definidas pode ser uma arma factível para as organizações enfrentarem as suas batalhas diárias.

\section{Iniciativa estratégica empresarial}

No âmbito da administração, a estratégia é associada à tomada de decisão que envolva toda a organização ou parte dela, assim variando de nível estratégico (o que fazer?), em seguida o tático (como fazer?) e o operacional (fazendo!). As estratégias são elaboradas para estabelecerem as condições que a empresa possui para se relacionar com o ambiente, por isto são dinâmicas.

A iniciativa estratégica empresarial pode ser mensurada pelo grau com o que os gestores se inclinam para satisfazerem as expectativas dos stakeholders externos. Meznar e Nigh (1995) propuseram algumas estratégias 
como forma de caracterizar estas iniciativas, e as utilizaram em sua pesquisa com o intuito de mensurar o grau com que os gestores se proporiam a serem os pioneiros ou liderar outras empresas a adotá-las.

As táticas apresentadas por Meznar e Nigh (1995) forma referentes a: Adotar políticas que estejam em conformidade com as novas expectativas sociais; Independer do que o setor assume como certo e errado, ético e antiético, para adotar novas políticas relacionadas com as questões sociais; Esperar até que leis sejam aprovadas para então realizar atividades em conformidade com as normas estabelecidas; Definir o que é certo e errado a fazer para ser visto pela sociedade como uma empresa cidadã; Cumprir com obrigações tributárias para estar em conformidade com a lei.

Existem gestores que enfatizam a competição, o individualismo e a autoeficiência empresarial por meio de usufruir ao máximo do ambiente sem interagir com ele (FREEMAN; McVEA, 2001). Para Meznar e Nigh (1995), os gestores responsáveis pela avaliação e escolha da estratégia, juntamente com assessoria jurídica especializada, tentarão defender os interesses da firma com relação às demandas sociais, configurando a adoção de postura buffer.

0 resultado da pesquisa empírica de Meznar e Nigh (1995) foi que as empresas que adotaram a postura buffer para stakeholders sociais e políticos tiveram uma correlação baixa e muito baixa com as iniciativas sociais $(0,26$ e 0,06 , respectivamente). $\mathrm{Ou}$ seja, quanto mais buffer for a postura da empresa, menos ela terá iniciativa para se antecipar às expectativas e estar em conformidade com que esperam seus stakeholders.

A consequência destas iniciativas é que estas empresas que adotam este tipo de postura gerencial são pouco prováveis de terem iniciativas estratégicas empresariais e se adaptarem às mudanças das expectativas sociais e regulamentações de órgãos do governo.

\section{Hipóteses do estudo}

Todas as hipóteses da pesquisa são apresentadas a seguir:

- H1: As incertezas macroambientais contribuem de forma positiva para que empresas adotem a postura de proteção Buffer;
- H2: O tamanho de uma organização contribui de forma positiva para que ela adote a postura Buffer;

- H3: A importância dos recursos possuídos pela organização contribui de forma positiva para que ela adote a postura Buffer;

- H4: 0 nível de visibilidade possuído pela organização contribui de forma positiva para que ela adote a postura Buffer;

- H5: Tamanho é positivamente associado à visibilidade pública;

- H6: As iniciativas estratégicas empresariais são negativamente associadas à adoção da postura Buffer.

Considerando estas hipóteses, partiu-se para um estudo de campo, a partir da percepção de que uma análise consistente somente pode ser procedida a partir do que os próprios gestores têm a informar. Os detalhes dos procedimentos e decisões do trabalho de campo estão apontados no item seguinte.

\section{Metodologia}

Este item apresenta os procedimentos metodológicos adotados no desenvolvimento da pesquisa. Adicionalmente, decidiu-se que os procedimentos básicos de análise seriam baseados em técnicas quantitativas, o que implicou na coleta de dados por meio de um questionário do tipo estruturado.

0 questionário utilizado consistiu numa adaptação do original, proposto por Meznar e Nigh (1995). Nesta adaptação definiu-se que ele seria desenvolvido em duas partes: inicialmente foram apresentadas questões de múltipla escolha, para levantar informações gerais e sociodemográficas sobre os respondentes; a segunda parte tratava dos tópicos centrais da pesquisa.

A única variável incluída no instrumento, que o faz diferir do original de Meznar e Nigh (1995), foi a inserção da variável observável 'Faturamento Anual Bruto', que utilizou os critérios do BNDES para classificar as empresas pelo porte. Todos os itens foram mensurados por uma escala de Likert de cinco pontos.

Depois dos procedimentos preliminares (ajustes do instrumento, submissão a outros pesquisadores e pré-teste) o instrumento foi aplicado, seguindo as seguintes delimitações: 
Universo da pesquisa: o universo foi constituído pelos gestores de empresas de diversos setores da indústria, do comércio e de serviços de Fortaleza e sua Região Metropolitana. 0 tamanho do universo não pôde ser definido;

Amostra: a amostra total foi de 74 respondentes, abordados diretamente em diferentes locais, selecionados conforme a acessibilidade e a conveniência;

Método de coleta: a coleta de dados foi procedida pelos autores. 0 procedimento básico consistiu em visita a cursos superiores de especialização lato sensu em gestão. Os pesquisadores partiram do pressuposto de que nestes locais há uma grande concentração de gestores e proprietários de empresas que querem se especializar. 0 acesso à sala de aula foi realizado após autorização dos professores. A única restrição imposta pelos pesquisadores era de que os respondentes não poderiam ser de instituições de gestão pública e não gestores. Os questionários da amostra foram aplicados nos meses de maio e junho do ano de 2009.

Na fase de análise dos dados empíricos, procedeu-se inicialmente à avaliação exploratória (AFE) preliminar, com a verificação de valores faltantes (missing values), assim como da existência de valores atípicos (outliers), especialmente nos itens dos construtos. Os procedimentos realizados não indicaram a necessidade de intervenções. Em seguida, foi feita a apresentação descritiva dos resultados das variáveis categóricas.

Após esta fase, especificamente para os itens de cada um dos construtos, procedeu-se à avaliação da confiabilidade por meio da medida Alpha de Cronbach, considerado adequado para medir a consistência de conjuntos de variáveis usadas para medir um mesmo construto (MALHOTRA, 1999).

Durante a AFE, foi observado indício de colinearidade entre os indicadores de "Tamanho" e "Visibilidade". A existência de colinearidade significa evidência de relação entre duas variáveis independentes. Entretanto, observou-se que a exclusão de qualquer uma delas não modificou o coeficiente de determinação do modelo $\left(\mathrm{R}^{2}\right)$.

Nos casos em que houve uma boa confiabilidade e adequação da estrutura fatorial, foram extraídos as médias e os desvios-padrão de cada uma das variáveis independentemente, e em seguida da medida geral do construto, com composição pela média das entradas das variáveis componentes de cada construto. Neste caso, além da confiabilidade, verificou-se ainda a estrutura fatorial, como forma de assegurar condições para a composição de variáveis (BAGOZZI; EDWARDS, 1998). A partir dos resultados agregados dos construtos, e como forma de atender ao primeiro objetivo do estudo, as médias e os desvios-padrão de cada um dos construtos foram extraídos e analisados.

Depois de avaliados os resultados de cada construto em separado, e como forma de atender ao segundo objetivo do estudo, os dados foram submetidos a uma análise de regressão múltipla. 0 propósito desta fase foi verificar a importância relativa de cada uma das dimensões na adoção da postura buffer.

Todos os procedimentos estatísticos foram desenvolvidos com suporte nas recomendações de autores especialistas nas técnicas utilizadas (MALHOTRA, 1999) e foram realizados por meio do software estatístico SPSS.

\section{Resultados}

De posse dos dados, foram extraídas as médias e os desvios-padrão de todas as variáveis da pesquisa. Em seguida, as variáveis foram analisadas em termos de confiabilidade, a partir do coeficiente Alpha de Cronbach, que, segundo Freitas et al. (2000), é a medida que afere se os itens da escala medem efetivamente a mesma coisa. 0 valor limite mínimo aceitável indicado na literatura é de 0,6 (de 0 a 1), e os resultados mostraram que o valor mínimo foi superado por todos os construtos (o mínimo verificado foi de 0,764 , na dimensão 'Iniciativa estratégica empresarial', o que indicou uma análise fatorial exploratória confiável na mensuração de cada construto.

Em seguida, procedeu-se à agregação das variáveis, gerando assim cinco novas variáveis. Os resultados dos Alphas, das médias e dos desvios-padrão das cinco variáveis agregadas podem ser visualizados na Tabela 1.

\section{Resultados descritivos, análise dos construtos}

Para este estudo, as variáveis utilizadas foram agrupadas por construto e foram extraídas as médias e os desvios (cf. critério de análise utilizado por COSTA et al., 2008). Pelos resultados, pôde-se verificar o seguinte (dado que a escala utilizada foi de 5 pontos): valores de média até 3 são baixos, de 3 a 4 são intermediários, e de 4 a 5 são elevados; para os 
desvios-padrão, valores até 0,8 são baixos, de 0,8 a 1,0 são médios, e acima de 1,0 são elevados.

Para o grupo 'buffer', a média ficou em um nível baixo $(2,62)$, indicando que as estratégias e táticas adotadas pelas empresas não são tão fortes para modificar ou se proteger do ambiente na qual estão inseridas. 0 desvio-padrão $(0,94)$ foi intermediário, indicando que há uma certa variação na resposta da amostra quanto à adoção desta postura;

A média para 'Incerteza ambiental' foi intermediária $(3,52)$, e o desvio de 0,78 . A indicação é que os gestores enfrentam um ambiente com certas turbulências e complexidades, provavelmente vindas de agências reguladoras do governo ou de grupos organizados. 0 desvio-padrão foi baixo, sinalizando pouca dispersão em torno da média;

A média do construto 'Iniciativa estratégica' foi considerada no limite como intermediária $(3,89)$, em compensação o desvio-padrão foi baixo $(0,76)$. Estas evidências sinalizam que os gestores respondentes adaptam suas empresas às exigências da sociedade e estão em conformidade com as suas expectativas. 0 desvio-padrão foi baixo, sinalizando pouca dispersão em torno da média;

A média para 'visibilidade' foi percebida como em nível intermediário $(3,48)$, com um elevado desvio-padrão (1,37). A indicação é que muitas das empresas pesquisadas são citadas nos meios de comunicação. Entretanto, houve muita dispersão em torno da média;

A média da variável 'Importância dos Recursos' foi considerada baixa $(2,16)$, conforme critérios estabelecidos. Entretanto, o desvio de opinião foi elevado (1,39). A indicação é que os produtos/ serviços prestados pelas empresas à sociedade são supérfluos (não são extremamente essenciais à sobrevivência da população), porém as respostas foram bastante divergentes, elevando assim o desvio-padrão.

Para uma análise preliminar pode-se concluir que, devido à amostra ser composta em sua grande maioria por pequenas e médias empresas $(65,7 \%)$, as empresas evidenciaram possuírem pouco poder para barganhar seus interesses. As médias para todos os construtos não passaram de intermediária, sinalizando que as variáveis externas não influenciam fortemente as empresas a adotarem postura gerencial buffer intensamente.

Apesar destes resultados não serem generalizáveis, trata-se de uma evidência empírica que não destoa, acredita-se, do universo geral das pequenas e médias empresas. Este resultado serve, portanto, de referencial comparativo para outros esforços de pesquisa com objetivos semelhantes.

\section{Análise das hipóteses}

Para verificação das hipóteses, procedeu-se uma análise de regressão múltipla pelo método enter, na qual o construto buffer foi colocado como variável dependente, e as cinco dimensões (Incerteza ambiental, Iniciativa estratégica, Tamanho, Visibilidade, Importância dos recursos) foram colocadas como variáveis independentes.

Verificou-se que o melhor modelo para a variável dependente foi aquele no qual a variável buffer ficou bem explicada $\left(R^{2}=0,430 ; F=8,835, p<0,001\right)$ pelas variáveis independentes, com influência significativa de todas as variáveis independentes. Diante dos resultados (ver Tabela 2), tem-se a análise das hipóteses:

- A hipótese H1, que afirmava que as incertezas macroambientais são positivamente correlacionadas com a adoção da postura Buffer, foi aceita $(\beta=0,483 ; p<0,001)$, significando que quanto maiores forem as incertezas do ambiente em que a empresa está inserida, mais ela vai criar estratégias para modificar o ambiente a seu favor ou proteger-se das ameaças ambientais e mantê-las longe de influenciar suas estruturas organizacionais;

- A hipótese H2, que afirmava que o tamanho da organização está positivamente correlacionado com a adoção da postura Buffer, foi aceita $(\beta=0,544 ; p<0,001)$, evidenciando que, dependendo do tamanho da empresa, ela tem interesse em modificar o ambiente para se beneficiar ou de simplesmente se proteger das ameaças ambientais;

- A hipótese H3, que afirmava que a importância dos recursos oferecidos pela organização está positivamente correlacionada com a adoção da postura Buffer, foi refutada $(\beta=-0,062$; $\mathrm{p}>0,001)$. Neste caso, a adoção de posturas para se proteger ou modificar o ambiente não tem relação com o tipo de produto/serviço que a empresa fornece, principalmente pela significância estatística que extrapolou o limite tolerável; 
- A hipótese H4, que afirmava que a visibilidade pública da organização está positivamente correlacionada à postura Buffer, também foi aceita $(\beta=0,560 ; p<0,001)$. Assim, temos a evidência de que quanto maior for a exposição da empresa perante seu público, maior o interesse dela em modificar o ambiente ou de proteger seus ativos dele;

- A hipótese H5, que afirmava que o tamanho da organização está positivamente correlacionado à sua visibilidade pública, foi aceita $(\beta=$ $0,631 ; p<0,001)$, indicando que quanto maior for o tamanho da organização, maior será a visibilidade dela perante seu público;

- A hipótese H6, que afirmava que as iniciativas estratégicas empresariais são negativamente correlacionadas com a adoção da postura Buffer, foi rejeitada $(\beta=0,534$; $\mathrm{p}<0,001)$. Portanto, há evidencias de que a relação seja inversa, ou seja, quanto mais a empresa tem a postura de modificar ou se proteger do ambiente, mais ela adota iniciativas empresariais.

Uma síntese destes resultados encontra-se na Tabela 2. Considerando conjuntamente os fatores de influência na adoção de postura buffer, pode-se verificar que quatro das seis hipóteses foram aceitas, o que ilustra a necessidade de um cuidado especial por parte dos gestores organizacionais com relação aos aspectos ambientais para as tomadas de decisão.

Aspectos controláveis como tamanho e visibilidade também são correlacionados, indicando que as firmas dependem dos recursos possuídos para decidirem se irão se fechar ou não às expectativas do ambiente. A hipótese H5, que correlacionou visibilidade e tamanho, também foi aceita, indicando que estes construtos são positivamente associados.

Tabela 1 - Medidas dos construtos

\begin{tabular}{lccc}
\hline Construtos & Alpha & Média & Desvio-padrão \\
\hline Postura buffer & 0,863 & 2,62 & 0,94 \\
Incerteza ambiental & 0,830 & 3,52 & 0,78 \\
Iniciativa estratégica & 0,764 & 3,89 & 0,76 \\
Tamanho & 0,877 & 3,01 & 1,03 \\
Visibilidade* & - & 3,48 & 1,37 \\
\hline Importância dos recursos* & - & 2,16 & 1,39 \\
\hline
\end{tabular}

Legenda: * Os construtos 'Visibilidade e 'Importância dos Recursos' são diretamente observáveis, ou seja, não requerem itens para serem formados, por isso não puderam ser submetidos à análise fatorial.

Tabela 2 - Modelo de regressão

\begin{tabular}{lcccc}
\hline Antecedentes & Valor $\mathbf{B}$ & Valor t & Sig. (p-value) & Resultado \\
\hline Incerteza ambiental & 0,483 & 4,233 & 0,000 & Aceita \\
Importância dos recursos & $-0,062$ & $-0,479$ & 0,633 & Refutada Aceita \\
Tamanho & 0,544 & 5,016 & 0,000 & Aceita \\
Visibilidade & 0,560 & 3,01 & 0,000 & Aceita Refutada \\
$\begin{array}{l}\text { Tamanho e Visibilidade } \\
\text { Iniciativa estratégica }\end{array}$ & 0,534 & 4,978 & 0,000 & \\
\hline
\end{tabular}

Fonte: Dados da pesquisa. 


\section{Considerações finais}

0 artigo teve como objetivo central avaliar o nível de adoção da postura gerencial de proteção buffer adotada pelas PMEs da Região Metropolitana de Fortaleza, e contribuir para o entendimento de como as organizações, em meio às constantes mudanças externas e também internas, predispõem as suas estratégias se relacionando com o ambiente. Levando em conta o desenvolvimento teórico apresentado e os resultados provenientes da entrada em campo, tem-se a confiança de que este objetivo foi alcançado.

Os autores também acreditam ter elevado o nível de conhecimento sobre as posturas gerenciais adotáveis por organizações empresariais, a relevância de tal feito está na quantidade de trabalhos desta natureza, ainda poucos e exploratórios. Neste sentido, os resultados aqui apresentados juntam-se a outros, e os autores sabem que existe o potencial de trazer contribuições para pesquisas vindouras sobre o gerenciamento stakeholders, especialmente no âmbito das posturas gerenciais estratégicas.

Pelos resultados de trabalho de campo, os autores acreditam que o problema de pesquisa foi respondido com êxito, tendo sido possível avaliar a intensidade com que as variáveis pesquisadas estimulam os dirigentes a adotarem a postura de proteção buffer, além de analisar os fatores de influência sobre a adoção desta postura. Em termos teóricos, esta pesquisa se enquadra no contexto do gerenciamento estratégico, apesar de ter se utilizado de outras teorias. $\mathrm{O}$ artigo se soma a outros semelhantes, principalmente aqueles de natureza quantitativa e de levantamento bibliográfico.

A teoria da dependência dos recursos se mostrou em parte apropriada para promover um modelo que explicasse a adoção de comportamento buffer. Neste aspecto, Meznar e Nigh (1995) chegaram à mesma conclusão deste artigo, entretanto, para eles, a hipótese da importância dos recursos possuídos foi aceita, acredita-se que pelo fato de as empresas por eles pesquisadas terem um porte bem maior que as deste trabalho.

Conforme a sugestão de Meznar e Nigh (1995) para que pesquisadores se aprofundassem no estudo da relação entre visibilidade e atividade empresarial buffer, os resultados desta pesquisa destoaram dos estudos destes autores. Após a entrada em campo, foi verificado, pela análise de regressão, que a hipótese foi aceita, e que a relação é forte. No estudo original a hipótese não foi confirmada e a relação foi bem fraca.
Os resultados encontrados nesta pesquisa sobre a relação entre postura gerencial e incertezas ambientais possuem algumas implicações até dedutíveis. Se as atividades empresariais do tipo bloqueio e proteção buffer têm relação positiva com o meio ambiente e suas incertezas, é prudente que comece a se instalar dentro das empresas um departamento que acompanhe os cenários econômicos, sociais, políticos, dentre outros. A tendência é que os setores fiquem hipercompetitivos, assim como afirma D'Aveni (1995). Meznar e Nigh (1995) também fizeram esta previsão em seu estudo.

Este artigo possui limitações, e elas estão nos resultados encontrados. Estes foram restritos a uma amostra que não condiz com o total do universo das pequenas e médias empresas da Região Metropolitana de Fortaleza. A sugestão que os autores deixam para pesquisas futuras é que este estudo seja replicado em um número maior de empresas.

Adicionalmente, acredita-se ser fundamental para estudos futuros testar as mesmas variáveis preditoras. Em pesquisas futuras, será possível analisar simultaneamente a adoção de posturas diferentes, mas não mutuamente exclusivas com as mesmas variáveis preditoras, e assim predizer quando as empresas enveredarão por uma determinada postura ou por ambas.

\section{Referências}

ANTUNES, E. A. Características da complexidade do ambiente e do processo contínuo de formação de estratégias e relação entre ambos. 2006. 212 f. Dissertação (Mestrado em Administração) - Universidade de Brasília, Brasília, 2006.

BAGOZZI, R. P.; EDWARDS, J. R. A general approach for representing constructs in organizational research. Organizational Research Methods, v. 1, n. 1, p. 45-87, 1998.

BEDÊ, M. A. et al. Onde estão as micro e pequenas empresas no Brasil? São Paulo: SEBRAE, 2006.

BRAMMER, S.; MILLINGTON, A. Firm size, organizational visibility and corporate philanthropy: an empirical analysis. Business Ethics: A European Review, v. 15, n. 1, p. 6-18, 2001.

BROWN, S. L.; EISENHARDT, K. M. Estratégia competitiva no limiar do caos: uma visão dinâmica para transformações corporativas. São Paulo: Cultrix, 2004. 
CARDOSO, A. C. F.; SCHENINI, P. C.; RENSI, F. Forças que convergem para a postura empresarial ética e socialmente responsável. In: CONGRESSO VIRTUAL BRASILEIRO DE ADMINISTRAÇÃO, 4., 2004, São Paulo. Anais... São Paulo: COVIBRA, 2004.

COSTA, F. J. et al. Atitudes dos estudantes de cursos de administração quanto às disciplinas de métodos quantitativos: desenvolvimento de uma escala de mensuração. Fortaleza: EDUECE/CMAAd, 2008.

D’AVENI, R. Hiper competição. Rio de Janeiro: Campus, 1995.

FAGUNDES, J. A. et al. Proposta de pesquisa em contabilidade: considerações sobre a teoria da contingência. Revista de Contabilidade do Mestrado em Ciências Contábeis da UERJ, v. 13, n. 2, p. 1-13, 2008.

FERRELL, O. C.; FRAEDRICH, J.; FERRELL, L. Ética empresarial: dilemas, tomadas de decisões e casos. Rio de Janeiro: Reichmann \& Affonso, 2001.

FOSSÁ, M. I. T.; SGORLA, F. A visibilidade midiática das práticas de responsabilidade social como estratégia de legitimação organizacional. In: CONGRESSO BRASILEIRO DE CIÊNCIAS DA COMUNICAÇÃO, 31., 2008, Natal. Anais... Natal: INTERCOM, 2008.

FREEMAN, E. R. Strategic management: a stakeholder approach. Boston: Pitman, 1984.

FREEMAN, R. E.; McVEA, J. A stakeholder approach to strategic management. In: FREEMAN, R. E.; HARRISON, J. S.; HITT, M. A. (Ed.). The Blackwell handbook of strategic management. Oxford, UK: Blackwell, 2001.

FREITAS, H. et al. O método de pesquisa survey. Revista de Administração, v. 35, n. 3, p. 105-112, 2000.

HALL, R. H. Organizações: estruturas, processos e resultados. São Paulo: Pearson Prentice Hall, 2004.

HARRISON, J. S.; ST. JOHN, C. H. Managing and partnering with external stakeholders. Academy of Management Executive, v. 10, n. 2, p. 46-60, 1996.

HENRIQUES, I.; SADORSKY, P. The relationship between environmental commitment and managerial perceptions of stakeholder importance. Academy of Management Journal, v. 42, n. 1, p. 87-99, 1999.

LEAL, A. S. S. A influência de fatores ambientais e organizacionais sobre os condicionantes do relacionamento interorganizacional. 2005. 154 f. Dissertação (Mestrado em Administração) - Universidade Federal do Paraná, Curitiba, 2005.
LOWENDAHL, B.; REVANG, O. Challenges to existing strategy theory in a postindustrial society. Strategic Management Journal, v. 19, n. 8, p. 755-773, 1998.

MALHOTRA, N. Pesquisa de marketing: uma orientação aplicada. Porto Alegre: Bookman, 1999.

MEZNAR, M. B.; NIGH, D. Buffer or Bridge? Environmental and organizational determinants of public affairs activities in american firms. Academy of Managnatent Journal, v. 38, n. 4, p. 975-996, 1995.

MOLINARI, S. K. R.; GUERREIRO, R. Teoria da contingência e contabilidade gerencial: um estudo de caso sobre $o$ processo de mudança na controladoria do Banco do Brasil. 2004. Disponível em: <http://www.congressousp.fipecafi. org/artigos12004/418.pdf>. Acesso em: 20 jun. 2009.

MOTTA, P. R. Gestão contemporânea: a ciência e a arte de ser dirigente. Rio de Janeiro: Record, 1991.

POST, J. E. et al. Managing publiaffairs function. California Management Review, v. 26, n. 1, p. 135-150, 1983.

PRADO, E. P. V.; TAKAOKA, H. Um modelo para análise da terceirização da tecnologia de informação. In: SEMINÁRIO EM ADMINISTRAÇÃO FEA-USP, 5., 2001. São Paulo. Anais... São Paulo: SEMEAD, 2001.

PFEFFER, J.; SALANCIK, J. R. The external control of organizations: a resource dependence perspective. New York: Harper \& Row, 1978.

SCOTT, W. R. Organizations: rational, natural and open systems. New Jersey: Prentice Hall, 1998.

TEIXEIRA, R. M.; ANDRADE JÚNIOR, A. L.; BANGANGA, S. F. Recursos humanos nas pequenas e médias empresas: um enfoque dos anos 90. In: ASSOCIAÇÃO NACIONAL DE PÓSGRADUAÇÃO E PESQUISA EM ADMINISTRAÇÃO, 22., 1998, Foz do Iguaçu. Anais... Foz do Iguaçu: EnANPAD, 1998.

Recebido: 28/07/2011

Received: 07/28/2011

Aprovado: 29/08/2011

Approved: 08/29/2011 